\title{
Dealing with poverty, health and maternal child survival: The Organisation of African Independent Churches perspective
}

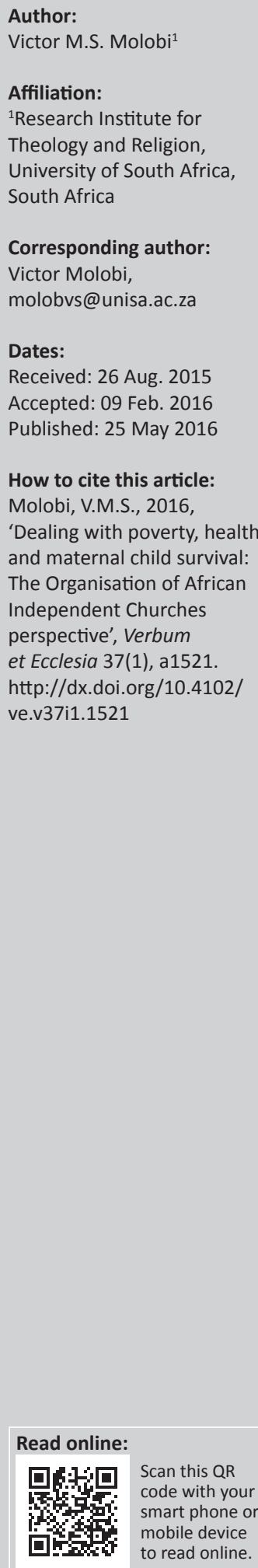

The Organisation of African Independent Churches (OAICs), as a representative of the African Independent Churches (AICs) across the African continent and in the Diaspora, disclosed that poverty has its own culture, and this was also confirmed by their undertaking of the Millennium Development Goals. AICs are commonly classified under the disadvantaged groups in the communities they inhabit. As a consequence, it cuts across their spectra as well. Members of these churches are domestic workers, cheap labour, factory workers, and unemployed. Often they come together with men of cheap labour and coupled as husbands and wives, forgetting their families in the rural regions where they came from. Many children are kept in these dark situations and poverty affects them badly, because for most of them they hold tempos without any guarantees for long lasting usage. This article will investigate how the AICs are affected and survive in these sites and the use of the OAIC in salvaging it. A participatory methodology will be used.

Intradisciplinary and/or interdisciplinary implications: This article has implications on the disciplines of development studies, gender studies, political science and government's policymakers on the efforts the AICs are making in alleviating poverty among children and youth in a holistic manner.

\section{Introduction}

\section{Background}

The Organisation of African Independent Churches (OAIC) is the representative body that brings together African Independent Churches (AICs) in the African continent. It provides them a forum for sharing their cares and hopes, and enables churches to minister effectively to the needs of their members and their communities. The discussed topic is borrowed from part of their vision which states:

We are the African people [sic] transformed by the good word of Christ to live an abundant life in the community for their children and the Earth. The OAIC mission work was also to bring the African Independent Churches together in society and to equip and enable them to preach the Good News of Jesus Christ in word and deed. (Lubaale, Padwick \& Gituto 2009:10)

Because the AICs have been affected badly by poverty, being one of the researchers and a recognised partner with them, it is imperative to assist in unpacking some of the challenges of research they want to solve them. Poverty is one of those pervasive problems. Several workshops and group discussions in Nairobi, Kenya were organised to deal with poverty among the AICs across the African continent. The interest for such gatherings came from the encouragement and experiences of their partners.

OAIC has consistently worked with other Christian churches and governing bodies. These included both the evangelical and ecumenical bodies. Through these various partnerships, OAIC seeks to share AICs insight and values, as well as learning from other Christian traditions. ${ }^{1}$ The experiences from these partnerships helped the OAIC to understand the problems and needs of the AICs from the global perspective. Thus, the challenge of poverty is not for the AICs alone,

1.For instance, OAIC partnered with the All African Conference of Churches (AACC), African Evangelical Faith Based Organizations and Fellowships, Christian Association of Nigeria, the Botswana Council of Churches, National Council of Churches of Kenya (NCCK), the Ufungamano Inter- Religious Forum, and the Inter-Religious Council of Kenya (IRCK), Global Christian Forum and the World Conference of Religions for Peace (WCRP), and, lastly, the member of the World Council of Churches (WCC). South Africa has been a member of the OAIC since its development in 1978. Zimbabwe is in a process of being roped in as a member. This whole effort is making the AICs more extensive in the continent and Diaspora. World Council of Churches, OAICs, 2015 World Council of Churches, http://www.oikoumene. org/en/church-families/african-instituted-churches/oaic. 
but rather it is affecting all communities in which AICs are in existence. AICs will play their part in this challenge from their own perspective.

The article will discuss the way in which the AICs through the OAIC are showing and privileging their own ways of dealing with poverty. Although we are aware of the broad issues that the AICs are dealing with regarding poverty, this article specifically focuses on maternal health and child survival. Here mothers and children are disadvantaged and ways and means of self-support and survival are necessary.

\section{Objectives}

This article aims to allow the exposure and experiences initiated by the OAIC on poverty, health, and maternal child survival. The AICs have been lacking muscle to vocally come out and stand for their faith without outsiders speaking for them. The article will look into how relevant government departments ${ }^{2}$ may be approached to help in benefiting the AICs from their existing policies. It will also look into the way AICs are categorised in terms of income status and their need for a multidimensional approach index and the relevance of measuring child poverty in particular. The topic of rethinking agriculture is seen as a crucial measure to where most of the AICs will be capable to work with less challenge than looking for employment in urban areas. Indeed, in urban areas are where AICs are domestic workers and are holding cheaper labour in numbers; and many of them are unemployed. Having this in mind, the number of those who are exercising or running small businesses are held into consideration to reflect on their financing initiatives in a positive light.

Because AICs are viewed as autonomous or even indigenous, it is imperative to associate with their efforts to direct the topics of hunger, based on how Christ dealt with it when addressing the hungry crowds. It was clear that during the missionary times a lesson was learnt from the way missionaries attempted to engage themselves in addressing the actual needs of the people including education and their livelihoods. The article's specific argument will be centred on how the AICs are addressing maternal health and child survival to ward off the unnecessary infant mortality.

\section{Methodology}

I was invited by the OAIC in Nairobi to assist them in writing the theology of the AICs across the African continent. The consultation took place from 2009 to date. During these years I have participated in their discussions about poverty and livelihood in Africa. As both consultant and the researcher, I opted for participatory, observation methodology which focuses on people's innate ability to address and resolve their own problems. This method helps to discover the behaviour and knowledge of AIC community groups from the young and old, male and female, and higher and lower status in the participatory processes (Progress Report August 1998). Their own environmental situation, needs and issues, constrain and plan to change are important to inform conclusions about their actions. This method of research is also regarded not just as the process of creating knowledge, but simultaneously as education and maturation of consciousness and mobilisation for action (Gaventa 1988:19). In our observation, it was clear that AIC prophetesses are not just healers; they also occupy the role of obstetrics. We looked into that practice and what experiences can be observed out of it. During this time I had numerous conversations with individual AIC leaders and ordinary church members about their experiences of poverty and livelihood in Africa.

\section{Literature review}

AICs are poor from both rural and urban perspectives. Narayan and Pettesh (2002:2) is saying that the poor are the true poverty specialists, because they are the only ones who can narrate about their experiences, priorities, reflections, and recommendations for poor kids, adult females, and men as indispensable. The book of Narayan and Pettesh (2002) entitled: 'Voices of the poor from many lands' was a wellresearched work. The team of researchers used the active, participatory method to collect their data. That book outlines in detail how people speak for themselves about their gruesome poor conditions and poverty affecting them. The other source came from the Adult Basic Education and Training (Education \& Training Unit [ETU] n.d.) document entitled: 'Understanding poverty development'. The most interesting, however, was the section on poverty statistics indicating that $56 \%$ of black people in South Africa are below the poverty line, while $60 \%$ are adult females. South Africa has one of the highest rates of income inequality in the world. The most productive $10 \%$ of the population receives almost half of the income and the shortest $20 \%$ pick up only $3.3 \%$ of the income.

Interesting all the same is the fact that the Zion Christian Church is located in the poorest part of Limpopo in the northern Province in South Africa and is still regarded as the richest AIC church in the country. Gauteng, the richest province in South Africa, has only 20\% (see ETU n.d.) under the poverty line. Eastern Cape Province is also very poor, but many of its people are working in Gauteng, which means that many people below the poverty line are found there. Limpopo province has fewer people, but $74 \%$ of the children there live in poverty.

\section{Theoretical framework}

Truly speaking the AICs have been associated with the general grassroots community and only certain aspects of interest for the researchers were the centre of focus. For instance, AICs were viewed from the burial societies, uniforms, syncretic biblical tendencies, and healing as some of their major aspects of their existence. They were never viewed as being concerned with poverty and economic issues. For instance the Human Development Index (IDH) combining income with 
life expectancy and literacy and the Index of Human Poverty (IPH), with five different 'dimensions' (United Nations Development Program), did publish comparisons between the rankings of countries according to these two indicators (IDH and IPH), but not with monetary measurements. Mestrum discovered that the indicators of Alkire and Santos (see Sabina et al. 2013) were different. If multidimensional poverty does not disappear with the eradication of income poverty, then the advocates of multidimensionality have a serious point to make. Mestrum (2011) continues to argue that:

In the poorest African, South Asian, and Latin American countries' services and a decent measure of living are almost lacking. Yet, measured at the $2.0 \$$ a day poverty line, an important majority of countries seem to take on major income problems. At this point, it is indeed income which is almost lacking. Services may be useable, but incomes do not allow having access to them. This is interesting, because it seems to suggest that for poor people less than $2 \$$ day - income is indeed the most significant problem. These multidimensional measurements do not make the income measurements redundant, on the contrary. They do point to the fact that services are badly needed in the poorest rural areas, but they also demonstrate that income poverty rapidly becomes more significant. (pp. 1-4)

The above information is keen to create awareness not only to the social-theological scientist, but likewise to the communities involved. In our example in the words of Kumalo (2003:45), development is necessary to convey a collective effort among the AICs to realise their self-identity. It is from this position that the OAIC wants to instil the culture of managing among its members. OAIC believes that effective participation among the AICs will help members shape decisions that cast their lives (Kumalo 2003:46). Adult females and men will be disempowered if they cannot do this right. Development and relief work should strengthen people's capacity to take part positively in social change in terms of both personal development and public activity.

\section{Results}

This section will attempt to answer the question: Can the AICs through the OAIC be able to help themselves to come out of the poverty and how? Here the effort is to exclude one's own interest, instead attempting to elicit the interest of the AICs themselves. Hence we will allow the debate to take its course in letting the voices of the AICs audible enough relating to what they can afford for themselves.

In the draft of their handbook on developing AICs, Lubaale et al. (2009) indicated that OAICs development of an HIV and AIDS programme helped them to rework their formal theological programmes after learning the importance of encouraging the AIC leaders and members to articulate their own visions. This happened after using the Participatory Learning Action method and the Participatory Rural Appraisal method (Opuka 2006).

These methodologies strengthen the importance of encouraging local AIC and the grassroots to focus on the struggles of average people to rebuild and strengthen their communities and better their lives (Padwick 2009:5). Theology, on the other hand, often centred on teaching what is normally known in Christian circles. It has tended to centre on the general rather than the local view of Christianity. Padwick further indicated that:

We also determined that it is precisely those AIC members who fought with the HIV and AIDS, poverty and lack of food, and who seek to be authorized through their religion. (p. 5)

The prompt action that was needed by the OAIC to strengthen their lives was revealed in the two discussed themes that took place in Kenya in 2012. The two themes were based on these themes: 'From promise to action on maternal and child survival' and 'Growing the harvest: rethinking agriculture and food security in sub-Saharan Africa'. The themes will be discussed in the following section.

\section{Understanding child poverty}

According to Lubaale, Padwick and Gituto (2009) the general secretary of the OAIC stated the following words:

Many 'African children' in Africa are still faced with many major challenges. Many are still out of school. High mortality rates and levels of poor health are due to malnutrition, malaria, and respiratory infections. These are problems directly related to poverty. (p. 20)

In response to this critical situation, the AICs are engaged in holistic child development. OAIC helps the AICs to support child development and family welfare at the community level. They strengthen the capacity of member churches to improve access of children and young people in health, education, and social protection. They mobilise the member churches to get involved in advocacy for children's policies and the effective provision of services.

\section{Understanding youth poverty}

It is estimated that nearly half of Africa's population is below the age of 15 , and $25 \%$ is between the ages of 16 and 25 (Lubaale et al. 2009:18). This predominantly young population presents numerous opportunities, but with it comes great responsibility. For example, there is high unemployment in Africa, which affects the acquisition of money to fund the technical and tertiary education, health care, nutrition, and investment for their future. There is a need for capacity-building to furnish services and opportunities for them.

To secure the rounded development and opportunity of the AIC for young people, OAIC had to facilitate the participation of young people within its structures and the leaders of its member churches (Lubaale et al. 2009:20). This facilitation is encouraging a solid focus in programmes and ministries for equipping young people with the capabilities and assets that they require for their livelihood. In that regard the AICs are able to equip their youth with marketable skills, making use of the micro-enterprise, savings and credit systems, health policies, and other phases of asset building and societal protection. Therefore, OAIC will want to equip 
young people so that they can bring up their part in shaping local, internal, and global policy and administration.

According to Mestrum (2011) poverty is, in every market economy, an income deficit. It is income that will permit people to sustain access to food, shelter, water and sanitation, education, and wellness care. Water, education, and wellness care are not specific needs of poor people, but of the entire country. Having said that one may ask, what about the squatters and rural areas where they usually do not have basic services. It should be clear that income poverty is not a relevant measurement for the situation of children because children cannot earn a livelihood or attain a decent standard of livelihood for themselves. In this instance, Mestrum (2011) calls it the multidimensional poverty' as the only correct approach because it constitutes part of composites that can sponsor even children against poverty.

Children living in poverty are also living with poor families (Mestrum 2011), thus they survive through what those families are surviving on. The large part of children and female adults of the AICs emerged from the same community of the poor, although they never complain about poverty as such. AICs view poverty comprehensively; the blame for it is put on lack of employment, housing, lack of rain, sickness, witchcraft, and ancestral dissatisfaction among others. These are what the OAIC views as the major challenges for the projection of their 'vision for a better world: abundant life for all in the community'. The next section will look into the OAIC understanding of the Bible and how it can be used to address poverty.

\section{Growing the harvest, the granary of the cross experience}

In the previous section we talked about the OAIC taking advantage of its partnerships. They have organised a conference entitled Growing the harvest: rethinking agriculture and food security in sub-Saharan Africa. ${ }^{3}$ On a theme, The granary of the cross, Rev Buri (2012), a youth director in the Saint Andrews Presbyterian Church in Nairobi, remarked that:

The church as a holistic liberator must liberate people from all forms of insecurities including food. God has supplied His creation with food from the start and food supply as a result remains a key church responsibility. Food shortage shows in numbers of people who sleep hungry; the number of food related conflicts. The African missionary model (Body health, Soul, Mind) including food for stomach should be seen as a new inclusion in the present context. The church must include food as part of its key areas of mission and participate in the 'spirits' (politics) of food. Lastly the necessary technical capacities must be built to cater where there is a need for food supply. (n.p.)

As a result challenges ranging from orphanages, falling houses, abandoned youth, unaffordable school fees, unemployment, divorces, homelessness, old age, disability, and begging for survival are some of the challenges strongly associated with impoverishment (Narayan \& Pettesh 2002:72-73). These challenges are among the main tasks which churches should speak about and encourage for their replacement for the better support. The members of the AICs should be seen as a constituent of the faith group developing from the grassroots community ripped by poverty that is destroying their hope. The poor have a tendency to tolerate the spiritual vitality, making them to endure their gruesome problems. That energy has made many degraded members of small churches to come on intermittently at various points in their spiritual life journey and mainly getting their voices heard. In addressing that factor, OAIC suggested other possible ways to deal with poverty.

\section{Speaking about food mission}

Buri (2012) suggested four types of churches which AICs had to establish to support communities towards storing food to relieve poverty among them and society at large. He identified the sowing church, sharing church, storing church, and the selling church. In a workshop to which I was part of we deliberated on his four suggested topics as follows.

\section{Sowing church}

This is the hands-on church whose symbols on the letterhead are 'seed and plough'. This church is driven by the account of the scriptures. A sowing church should be involved in quality seed distribution and such church should be in partnership with seed companies, including research institutes and departments dealing with farming. God sowed the first seeds and provided Adam and Eve with food. In that way God has taken food as His responsibility. He gave his peoples' land implying the grace of production. Lastly, God performed food miracles.

\section{Sharing church}

This church is the church that sets itself as the people's feeder. Its biblical inspiration came from the text that says: I was hungry, and you fed me 'instead of nothing' rather 'something' to consume. Think of the story of manna - why keep it and rot? The accounts of feeding the multitudes, especially the one where Jesus says 'You give them something to eat' Love your neighbour as yourself - sharing food is a way of loving.

\section{Storing church}

This is the church that determines itself as acting as the part of the food watchman. This church is driven by accounts in the scriptures. Joseph was brought up as a storage strategist. The miracle of Jesus feeding the multitude had even baskets to spare is ideal. Because of its reputation for storage, just like Christians were first called Christians at Antioch, to make it distinct from other storage facilities, the people in the neighbourhood would most likely call it: 'The Granary 
of the Cross'. This church is likely to look for a storage permit from the government to erect silos, and would also most likely partner with other faith-based organisations to defend the community-built domestic granaries. The storing church aims at the moderation of consumption and would probably be concerned about the gyms all around town to 'burn' food - they would probably host a big billboard saying 'do not burn a rather store it' or 'why burn it if you can burn it?'

\section{Selling church}

The selling church is one that engages directly with the food business. This church is driven by the level of the four lepers in Kings - where prices were brought down to incredible levels. The selling church will most likely borrow a term from the market - where people with the lowest monetary value are called the 'church prays'. And then you will find a bargaining person say 'please sell to me at the church-price'. The selling church has the aim of supplying food to non-producers. It is able to append to its church income for necessary commodities to the hapless masses. Influencing prices, there's the news report of Rev and Mrs Wanjau who opened a retreat centre and the players in the fields projected that all customers would change over to the Wanjau's because they would make their facility 'nearly for free'.

\section{Consuming church ${ }^{4}$}

In terms of the granary church model, including: sowing church, sharing church, storing church, and the selling church, the story of Selina Saban became a good example of the eating church as well. Her story was narrated at the conference and workshop of 'Vision for the better world' in Nairobi in 2009. ${ }^{5}$ She (Saban n.d.) indicated that:

Since the start of this project on food security I have gained several breakthroughs which have changed my mindset completely. Cultivation of drought resistant crops has benefited me immensely. Food is no longer a luxury like before. This has brought delight and pleasure in my household. The training received from the church and barazas (village gathering) have shown me new doors of prosperity. This stimulated our curiosity to try out the practices. We formed a youth group called Sinaya Youth Group comprising 26 members. This union has an enhanced exchange of production techniques and has made us think collectively as a group. (n.p.)

I started planting other drought resistant crops like cow peas, cassava, sweet potato, pumpkins, onions, and bananas that are fit for this ecological condition, something I was previously not aware of. This has enabled me to gain substantial skills in crop preparation and management. My family really enjoys variety and more nutritious meals. My living standards have tremendously changed from being a mere farmer who runs out of food year after another to a

4.This is not one of Buri's four suggested workshop topics; however i found it necessary to add 'Consuming Church' because the church does not only sow, store and sell, but it also consumes.

5.See 'Life has changed' -An account of two farmers (Saban n.d.). more reliable farmer who has a food supply irrespective of the month or season. The income level and health of my family has improved. My challenge now is in the choice of meal to have because there is plenty to choose from. I used to have one meal a day, or even none sometimes, but today I can enjoy three meals. Hosting a visitor today is a joy because I will have a good meal for them.

The whole community has experienced the same changes as we widely share and exchange views and discuss issues together. We always meet at the posho mills (milling machine) after the church service and during our 'chama' (mutual society) meetings. Our area Chief, his assistant, and Ministry extension workers have encouraged us more and promised to work with us closely. Unlike in the past when the youth and women were silent and only restricted to homestead chores, they have now become active participants during barazas and other workshops. Their position in the development in the community is beginning to take shape.

Through my improved income status from the sale of the surpluses, I have gained confidence in lobbying and advocating for the members of the society of the treasure hidden in this project. I am now willing and ready to use my experience to educate those still languishing in hunger and doubt, to rise up and adopt the farming of these crops and move away from buying food at exorbitant prices which render them poor and hungry.

This project, I believe, will reduce poverty, family and gender based violence, and malnutrition in our families, hence improving health, living standards, harmony, and education for all. We thank OAIC for the invaluable support, friendship, and partnership with us. May the Almighty God open more productive doors of abundance.

This story is not only about making money, but also eating to bring delight in the homes. There are a number of such stories that were shared at the workshop on 'Vision for better world' in Nairobi. The idea is for the AICs to be able to think broader towards not only the poverty alleviation but also financial freedom. Indeed, this data indicates that the AICs can also address maternal health and ward away the unnecessary infant mortality among them.

With the launching of OAIC's 5-year program, 'Visions for a Better World', the Livelihoods program began to focus not entirely on community level activities that are required to secure livelihoods and well-being, but likewise along the macro factors driving continued erosion and denial of livelihood capabilities. Consequently, the plan identifies the solution of economic mismanagement, weak policy formulation, historical denial and failure of states to confront inequality, and social vulnerability as key to the realisation of well-being.

The plan also identifies the resolution of imbalances in trade and climate change as critical to the realisation of well-being. In addition to initiating local and community activities to sustain livelihoods, the new approach also targets actions at 
national, regional, and international levels that are required to fetch about the much needed resolve. The new approach also focuses on helping AICs to use their spiritual and social capital as key resources for negotiating and enabling entry into the formal economy, and taking advantage of emerging economic opportunities and realities.

The OAIC are running the livelihood programmes aiming to mobilise member churches and their communities to understand and respond to issues of poverty, inequality, and other factors that affect their livelihoods. They also want to strengthen the ability of rural and urban populations to enhance their livelihoods through social entrepreneurship, community investing, and micro-enterprise. They want to support initiatives of poor urban households to improve their quality of life and advocate for policies that advance the rights of poor people to food security.

\section{The role of prophetesses to maternal care and survival}

Daneel (2007:221) has observed that the majority of the women healers deal specifically with women's reproductive functions and problems such as barrenness and family conflicts deriving from such conditions, pregnancies, childbirth, and infant care. Most of the spots where the prophetesses are consulting are regarded as healing centres, or clinics. Those positions are also seen as the motherhood centre in some spots. In South Africa childbirth is done in hospitals or at home and then a child is admitted to the government medical centres or hospitals for assessment and registration. The regime strongly discourages birth at home, preferring its own medical institutions of private hospitals and clinics. However, because of exuberant charges AICs and other poor people may not afford the fees and therefore prefer government hospitals in most cases.

Nevertheless the traditional methods of health and child rearing are still practiced in the rural areas for variant specific challenges. Childbirth in many African countries is seen as a sensitive matter. In rural areas some squatter camps are reserved for the traditional healers including prophets as well. This is in a way affirming Maimela (1985:71) when stating that:

The greatest attraction of the AICs is their open invitation to Africans to bring their fears and anxieties about witches, sorcerers, bad luck, poverty, illness, and all kinds of misfortunes to the church leadership. AICs are seeking to offer answers to every problem, not just to promise heaven after you die. (Oduro et al. 2008:75)

Traditional approaches to health have not had scientific verification for safety. It is from this perspective that Werner (1982) indicated that health advice should be provided even where there are no medical doctors. People should take the lead in their own health care. The difference to the AICs maternal health care may be the lack of health professional suggestions.
However, in terms of the new OAIC vision for better life, things seem to be changing a bit. The OAIC Health and Well-being program believes that good health is a prerequisite for much of what our communities and individuals can achieve. In order to build the ability of member churches and their communities to respond creatively, proactively, and effectively to the challenges of ill-health and HIV and/or AIDS, the program works with churches and communities to transform negative theologies and cultural understandings. The program also focuses on cultural, social, and legal systems that hinder men, women, and children from acting effectively to deal with the causes and impact of the pandemic (OAIC n.d.).

The OAIC Health and Well-being program brings together member churches and their communities to scale up their support for Persons Living with HIV and AIDS, to improve their livelihoods, and to increase their access to treatment and effective, affordable care. The program also works to secure appropriate action and commitment to all children who are vulnerable to the impact of HIV and AIDS and other causes that might hinder their family life, education, or well-being (OAIC n.d.).

\section{Organisation of African Independent Church took advantage of its partners}

Through the boost of their partners they looked into various options pertaining to how they could better their status towards livelihood. Conferences on 'Faith for life' in Nairobi and the 'Growing harvest' were real important to map the aim of the OAIC in guiding their member churches. Various workshops were held to promote the dream of AICs against poverty across the continent and the Diaspora. The topic of maternal health should not be considered as separate from the overall problem AICs faced with poverty.

The AICs maternal and child survival should be calculated from the factual context of these churches classified as the grassroots because of their poverty inclinations. OAIC's visions are based along the values and resourcefulness of African grassroots communities (Ubuntu). They are conveyed in songs, sermons, prayers, and dancing. The OAIC is motivated by the AIC members and millions of Africans who look forward to a society in which all can enjoy well-being. These visions are rooted in an African philosophy of animation in which care, reciprocity, acceptance, openness, and equality are core values. AICs are a Christian outworking of these African values and they remain important in the AICs ability to rally the masses to enlist with the challenges facing contemporary African societies. What is a way forward?

\section{Gender equality in education}

There is an important point here relating to the issue of gender, especially among the AICs. As much as the input made by the poor communities, they need to be given a careful hearing 
and observation before concluding anything about them. For instance, the late Archbishop Ngada and Mofokeng (2001:47), the president of the Association of Christian and Spiritual Association (ACSA), have indicated that in the:

AICs unlike many other churches, frequently women prophets, healers, deacons, priests, bishops, and archbishops are in the forefront. According to him gender is not as much of an issue as it is in the mainline churches. (p. 47)

Indeed, this is true, as I have researched more than 600 AICs denominations in and around Pretoria between (1992 and 2007) and have interviewed many women ministers, bishops, and archbishops, including prophets and prophetesses. In fact, what I have heard and observed was that some of the prophetesses appointed bishops, archbishops, and ministers who are both male and female at ease. However, the information used does affect women as the AICs are nevertheless regarded as part of the weaker community in terms economic resourcefulness. Thus, I am justified to mention the information below indiscriminately from the perspective of poverty margin.

There is a considerable intensity of literature to demonstrate that improvements in gender equality in education are of vital importance for reaching all the Millennium Development Goals (Abu-Ghaida \& Klasen 2004). In particular, it leads to higher growth and thus lower poverty as society makes better use of its human resources. This is manifested through reduced undernutrition and child mortality (as better educated mothers can ensure better care for their children), reduced fertility which lowers the demographic burden of a society, promotion of education for the next generation (as educated mothers ensure better education for their children), and increased bargaining power of women within families, which ensures greater access to resources for them (and also their children), thus becoming one important tool for empowerment (Abu-Ghaida \& Klasen 2004).

\section{African Independent Churches voice to governments and other stakeholders}

At the conference on Religion in Public Life at the MultiEvent 1999 in Cape Town, 11 community groups registered their voices in the government public policy for the first time. At that conference, which I, along with others representing the AICs, attended, Sokutu (1999:58) read a statement on behalf of 11 community-based organisations. From the voices in the periphery, she stated that:

We do not claim to speak for the many religious, community groups who work on the fringes of society but, like so many in South Africa, we are religious and community-based and from the fringes and we have something we believe is worth saying. Our religious character (Christianity) makes us a significant entity. One may say religion is obviously one social institution alongside others, such as economics and politics, and is found in church buildings, synagogues, mosques, temples, and shrines. This is true in one sense, but it is definitely not true of the religion of the Community Groups we represent. Our religion does not end in church buildings. It propels us into the public space to function as agents of transformation. (p. 58)

It was in the light of this that grassroots faith communities, including the AICs began to feel responsible to their fellow human beings. They too recognise that the South African government has various resources which they could tap to advance their missions of supporting their communities. To them it was the time to take action towards implementing their wishes. Attending the OAIC conference (Padwick 2009) on 'Visions for a safer world' in Kenya Nairobi was the ratification of the AICs driven by their religious values to get outspoken in matters of social transformation towards improving their lives and others.

\section{Conclusion}

Poverty undermines life and its dignity. It affects children, the youth, and everybody else. Poverty is cruel and this means it must be addressed holistically. The AIC churches deal with it at the grassroots level by empowering the base communities which are directly affected by poverty. They also work together with different partners in addressing community issues on poverty-related matters. In dealing with poverty the OAIC organised conferences which empowered the member churches. These conferences are used to help members who have lost hope because of impoverishment.

The section speaking about 'Food Mission' gives guidance on what the churches can do in addressing the issue of poverty and how it can help to feed the people. This is a critically important section in this article as it talks to the AIC and the church in general about what it means to be a church. The section is also about the OAIC's 5-year program: 'Visions for a Better World'. This plan helps the AIC to address factors which erode livelihood issues in communities. It helps the AIC to empower members.

Of great interest and importance is the fact that poverty affects women more than men. The OAIC noted this reality and came up with programs which are specific to women and their health issues. The AICs take the African reality into serious consideration and they address the problems having this reality in mind. They do not undermine the people because they are poor or women. They instead open up to them and uplift them.

The AICs also help to empower their members in genderrelated issues. As a result the voice of the AICs should be given careful attention. Gender is not as much of a factor for them as it is for the mainline churches. There are 'women prophets, healers, deacons, priests, bishops, and archbishops' in the AICs. There is a thing or two that the mainline churches can learn from them in relation to gender. Of great interest is the fact that the AICs have started to do what they did not do in the past; talking to the government. At the conference on Religion in Public Life at the Multi-Event (1999) in Cape Town 11 community groups registered their voices in the 
government public policy for the first time. The AICs are a significant group of the society and are on the fringe of the society. They help a significant number of members of the South African society. As a result, the AICs should not be overlooked. This is an important faith community in the country.

\section{Acknowledgements Competing interests}

The author declares that he has no financial or personal relationships which may have inappropriately influenced him in writing this article.

\section{References}

Abu-Ghaida, D. \& Klasen, S., 2004, 'The costs of missing the Millennium Development Goals on gender equity', World Development 32, 1075-1107. http://dx.doi. org/10.1016/j.worlddev.2004.02.003

Alkire, S., Conconi, A. \& Roche, J.M., 2013, Multidimensional/poverty Index 2013: Brief methodological note and result, viewed n.d., from www.ophi.org.uk/.../MPI2013-Brief-Methodological-Note-and-Results1

Buri, E., 2012, The granary of the cross - The sowing, sharing, storing and selling church, Unpublished report at the conference, viewed 18 September 2012, from http://www.oaic.org/?s=Buri

Daneel, M.L., 2007, All things hold together: Holistic Theologies at the Africa Grassrrots, Unisa, Pretoria.

Education \& Training Unit (ETU), n.d., Understanding poverty and development, viewed August 2015, from www.etu.org.za/toolbox/docs/development/poverty.html
Gaventa, J., 1988, 'Participatory research in North America', Convergence 24, 19-28. Kumalo, R. S., 2003, From desert to forests, CB Powell Cetre, Unisa, Pretoria.

Lubaale, N., Padwick, J. \& Gituto., M., 2009, Visions for a better world: Abundant life for all communities, OAIC, Nairobi, Kenya.

Maimela, S., 1985, 'Salvation in African traditional religions', Missonalia 13(2), 63-77.

Mestrum, F., 2011, 'Child poverty: Critical perspective', Social Work and Society: International Online Journal 9(1), 161-168.

Narayan, D. \& Pettesh, P., 2002, Voices of the poor from many lands, A Co-Publication of Oxford University Press, New York.

Ngada, N.H. \& Mofokeng, K.E., 2001, African Christian Witness: African Indigenous Churches, Cluster Publications, Pietermaritzburg, South Africa.

Organisation of African Independent Churches (OAIC), n.d., Our Programs: Health, viewed n.d., from http://www.oaic.org/?page_id=100

Oduro, T., Pretorius, H., Nussbaum, S. \& Born, B., 2008, Mission in an African way: A practical introduction to African Instituted Churches and their sense of mission, Cristian Leterature Fund (LF) and Bible Media (BM), Welington, Cape Town.

Opuka, E.H., 2006, Participatory Learning and Action (PLA), Zapf Chancery Research Consultants and Publishers, Nairobi, Kenya.

Padwick, J., 2009, From founding vision to contemporary Church: Theologies of today, OAIC, Nairobi, Kenya.

Saban, S., n.d., 'Life has changed' -An account of two farmers, viewed 25 March 2015 from http://www.oaic.org/?p=1329

Sabina, A., Adriana, C. \& Jose, M.R.A., 2013, Multidimensional Poverty Index 2013 Brief methodological note and results, viewed February 2013, from http://www. ophi.org.uk/.../MPI-2013-Brief-Methodological-Note-and-Results1

Sokutu, W., 1999, 'A voice from the periphery: A community groups perspective role of religon in public life', Transforming Public Life Religion in the Making of Public Policy and Cultural Values, Religion in Public Life, Multi-Event 99 Conference Proceedings, Cape Town, February 14-20, 1999.

Werner, D., [1977] 1982, Where there is no health doctor: A village health care handbook, Hesperian Foundation, California, USA.

World Council of Churches, OAICs, 2015, World Council of Churches, viewed n.d., from http://www.oikoumene.org/en/church-families/african-instituted-churches/oaic 